2. BAKKER, A.-Ueber die Bedeutung der Ascorbinsäure (Vitamin C) für den Stoffwechsel der Linse. Graefe's Arch.f. Ophthal., Vol. CXXXVI, p. 166, 1936.

3. Die Regeneration der verwundeten Linsenkapsel von Kaninchenlinsen in der Durchströmungskultur. Graefe's Arch.f.Ophthal., Vol. CXXXVI, p. 333, 1936.

4. The behaviour of a rabbit's lens and iris in a perfused culture. Acta Neerl. Morphol., Vol. I, p. 97, 1937.

5. U Ueber die Bedeutung der Regenbogenhaut für die Entstehung des Infrarotstars. Graefe's Arch.f. Ophthal., Vol. CXXXIX, p. 677, 1938.

6. Ueber Kohlensäureanhydrase in normalen and kataraktösen Linsen. Graefe's Arch.f. Ophthal., Vol. CXL, p. 543, 1939.

7. - Der Kohlensäureanhydrasegehalt verschiedener Augengewebe einiger Säugetiere. Ophthalmologica, Vol. CII, p. 351, 1941.

8. Die Aktivierung von Kohlensäureanhydrase und deren Bedeutung für einige Augengewebe. Biol. Zentralblatt, Vol. LXI, p. 502, 1941.

9. Aktivierung und Hemmung der Kohlensäureanhydrase. Enzymologia, Vol. XI, p. 70, 1943.

10. Zur Pathogenese der Galaktosekatarakt. Graefe's Arch.f. Ophthal., Vol. CXL, p. 531, 1939.

11. BoEve, W. J.-Diss, Groningen, 1927.

12. Brinkman, R. and Margaria, R.-Jl. of Physiol., Vol. LXXII, P6, 1931.

13. Goldman, H. - La génèse de la cataracte des verriers. Ann. d'Ocul., Vol. CLXXII, p. 13, 1935.

14. HAAN. J. DE.-Le mode de croissance des cellules migratrices dans les cultures in vitro à irrigation permanente. Bull. d' Histol., Tóme 4, No. 8, p. 1. 1927.

15. Vogt, A.-Schweiz. Med. Wochenschr., 475, 1929, I.

\title{
A CASE OF CONGENITAL VERTICAL SHORTNESS OF THE LIDS COMBINED WITH TETRASTICHIASIS*
}

B Y

\author{
DR. J. LANDAU
}

(From the Eye Department of the Hadassah University Hospital, Jerusalem, Director : Professor A. Feigenbaum).

CONGENITAL shortness of the lids was entensively studied by E. Fuchs ${ }^{12}$ in 1885. Congenital absence (ablepharon) or maximal shortness (microblepharon) of the lids has been observed repeatedly, partly in monsters, and also in otherwise normal individuals (cf. Manz, Handbuch. d. Ophthal., Graefe-Saemisch., Vol. II, p. 103). Stellwag described mainly the smallness of the lids in the horizontal diameter and the ensuing shortness of the palpebral fissure in this direction but not what, in the opinion of the writer, should be called vertical shortness of the lids. It was left to Fuchs to coin the expressions "height of the lid" and "vertical extension of the skin of the lid". "Height of the lid" is the maximum distance between the lid margin and the centre (i.e. half the breadth) of the eyebrow. In measuring this height the individual is asked to close the eyes

\footnotetext{
* Received for publication, December 20, 1946.
} 
lightly as though he were sleeping. "Vertical extension of the lids" is the maximal distance measured between the free lid margin and the centre of the eyebrow while the lid is held by the cilia and maximally stretched. These two measurements can be obtained only for the upper lid as there is no fixed demarcation between the lower lid and the skin of the cheek and no reference point exists for measuring the lower lid. The proportion between height and vertical extension of the lid is the co-efficient. Once this co-efficient falls below a certain value $(1 \cdot 5)$ the lid closire becomes abnormal: Normal closure of the lids is possible only if the height of the stretched upper lid is greater by at least one half than the height in a lightly closed state. The co-efficient varies from 1.5 in infants to 1.9 in old people. When the lid closure is not complete, lagophthalmos results. Complications of this condition are conjunctivitis and blepharitis (usually ulcerative). The cornea is rarely involved.

Von Herrenschwand ${ }^{3}$ published a case of congenital (vertical) shortness of the lids with ectropion of the palpebral conjunctiva. The lid margins were covered with conjunctiva, there were only a few eyelashes present and the lacrymal puncta were absent. The tarsi were normal.

Urmetzer ${ }^{4}$ presented a case of abnormal (vertical) shortness of the lids with marked hyperaemia of the lid margins, madarosis and a slight ectropion of the lower lid. Complete closure of the lids was impossible and the stretched lids were hardly longer than the relaxed ones.

The following case was observed at our out-patient department.

L. J., a boy aged'16 years, showed with closed lids a lagophthalmos of about 2.5 millimetres in both eyes (Fig. 1). The height of the

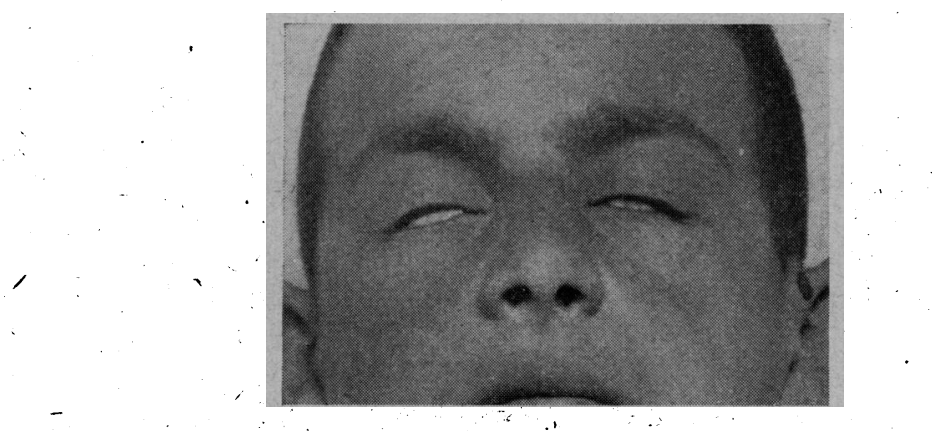

FIG. 1,

lids was 24 millimetres, the vertical extension 30 millimetres. The co-efficient was, therefore, $1 \cdot 24$. In both upper lids the cutaneous part of the lid margin was slightly everted, particularly in the temporal portion (Fig. 2). There were in both upper lids four rows 


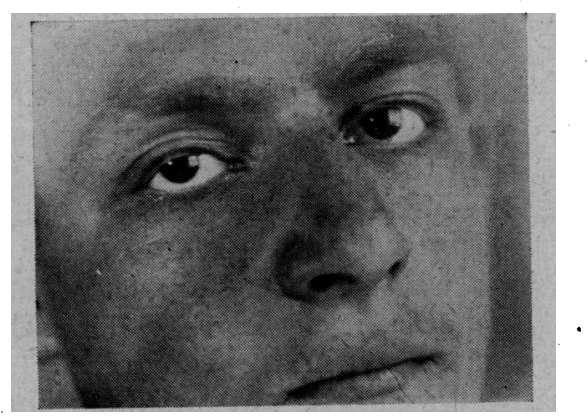

FIG. 2.

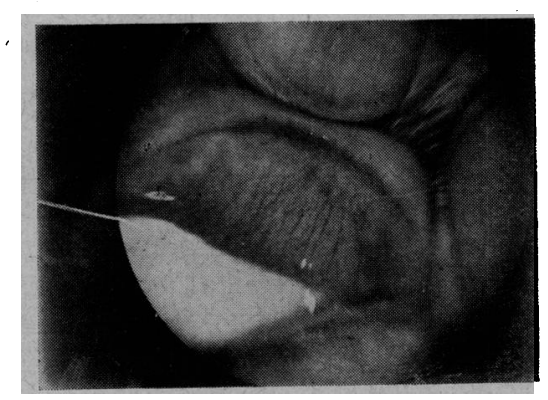

FIG. 3.

of equally well developed eyelashes. In the palpebral conjunctiva of both upper lids a fine dark line was visible in the subtarsal sulcus from which thin vertical streaks were extending (Fig. 3).

Visual Acuity: R.E. + 0.5 D. sph. c. + 0.5 D. cyl. $180^{\circ} 5 / 5$ (partly); L.E. + 0.5 D. sph. c. + 0.5 D. cyl. $180^{\circ} 5 / 5$ (partly).

There was no irritation of the lid margins or the conjunctiva. Apart from an acute blepharo-conjunctivitis in 1939, and a stye in 1941 no inflammatory conditions of the lids had occurred until now.

\section{Discussion}

To explain congenital distichiasis $\mathrm{Kuhnt}^{5}$ assumes a heterologous developmental anomaly. Cilia develop instead of Meibomian glands not only at the anterior but also at the posterior edge of the lid margin, owing to an abnormal preformation of unknown origin. Brailey $^{6}$ is also of the opinion that the epithelial invagination of the material destined to form the Meibomian glands failed to take.place and that eyelashes developed in their stead, corresponding exactly to the ducts of the glands. Erdmann ${ }^{7}$ conversely, considers the glands which belong to the posterior row of cilia as a formation of 
cilia and Meibomian glands from the same anlage, differentiation having failed to take place owing to an unknown cause. According to him the epithelial cone constituting the first anlage of both organs may develop into either an eyelash or an acinus of a Meibomian gland. An increase in the number of cilia, polytrichiasis or hypertrichosis, may be congenital or acquired. In congenital polytrichiasis the cilia are arranged in two or even three or four rows instead of only one, conditions which are called distichiasis, tristichiasis or tetrastichiasis ${ }^{8}$. Fuchs $^{9}$ reserves the term distichiasis for those rare cases where there are congenitally two regular rows of cilia in an otherwise normally developed, not inflamed lid. Aubaret ${ }^{10}$ also considers congenital distichiasis to be a rare anomaly.

The case presented above shows in addition to congenital vertical shortness of the lids, the rare picture of tetrastichiasis. The dark lines visible in the sulcus subtarsalis seem to be the hair follicles of the supernumerary cilia which have developed instead of the Meibomian glands. In spite of the existing shortness of the lids and the resulting lagophthalmos, the lid margins are altogether free from irritation, possibly because the cilia are regular and well dereloped. According to Schreiber ${ }^{8}$ the case of congenital symmetrical shortness of the lids with congenital symmetrical ectropion of the lid conjunctiva described by von Herrenschwand ${ }^{3}$ is unique in the literature. In the present case the partial eversion of the upper lid represents an abortive form of this condition.

While almost all cases of the Fuchs ${ }^{12}$ showed inflammatory changes of the conjunctiva and the lid margins, in the case described here there werenosigns of irritation. The cases of von Herrensch wand ${ }^{3}$ and Urmetzer ${ }^{4}$ had scanty cilia or no cilia at all (madarosis), whereas in our case there were four rows of regular, healthy cilia. According to the table of $\mathrm{Fuchs}^{2}$ the normal co-efficient for the age of 16 years is 1.6 while in our case it is 1.24 .

\section{Summary}

1. A case of congenital shortness of the lids in the vertical direction ("vertical shortness"), combined with tetrastichiasis, is presented.

2. A partial eversion of the cutaneous part of the upper lid margin was observed.

3. In spite of the existing lagophthalmos the eyes remained free from irritation or inflammation, possibly because of the co-existing hypertrichosis.

4. In the sulcus subtarsalis a dark line was apparent due to the hair follicles of the supernumerary cilia showing through the conjunctiva. These have probably taken the place of the Meibomian glands occupying their ducts. 


\title{
REFERENCES
}

1. Fuchs, E.-Kl. Miszellen, Arch.f. Augenheilk., Vol. XV. 1885.

2. Fuchs, E.-Zur Physiologie und Pathologie des Lidschlusses. Arch. $f$. Ophthal., Vol. XXXI, II. 1885.

3. VON HERRENSHWAND; F.-Ueber Ectropium conjunctivae palpebral congenitùm. Klin. Monatsbl. f. Augenheilk., Vol. LVI, p. 509. 1916.

4. Urmetzer, J.-Ein Fall von abnormer Kuerze der Lider. Klin. Monatsbl. f. Augenheilk., Vol. LIII, p. 240. 1914.

5. KuнNT-Ueber Distichiasis (congenita) vera Zeitschr. f. Augenheilk. Vol. I, p. 46. 1899.

6. BraIleX-Congenital distichiasis. Trans. Ophthal. Soc. U.K., Vol. XXVI, p. 16. 1906.

7. ERDMANN-Ein Beitrag zur Kenntnis der Distichiasis congenita (hereditaria). Zeitschr.f. Augenheilk., Vol. XI, p. 427. 1904.

8. SCHREIBER, L.-Die Krankbeiten der Augenlider. Handb. d. ges, Augenheilk. Graefe-Saemisch, pp. 358 and 573. 1924.

9. Fuchs, E.-Lehrbuch der Augenheilk., p. 637. 1905.

10. AUBARET, E.-Traité d'Ophtal., p. 862. 1919.

\section{RESEARCH IN ZURICH}

"Summary of the work on the pathological changes in the aqueous-humour and the blood-aqueous barrier, at Zurich." *

\author{
BY \\ M. J. ROPER-HaLi, D.O.M.S. \\ BIRMINGHAM
}

THE research at present being carried out at the University Augenklinik at $Z$ urich is devoted to the study of the aqueous humour and the blood-aqueous barrier.

This work was started by Professor Marc Amsler and his associates in Lausanne in 1940, and was mainly concerned with the albumen and cell-content of the aqueous in disease of the anterior segment. Since the Professor's appointment as Director the work has been continued and augmented at this clinic.

\section{The aqueous humour}

The specimen of aqueous humourisobtained in the following way:A smear and culture are taken from the conjunctival sac. The lids are then held open by a speculum, and a small scraping of corneal epithelium is taken from the lower and outer part of the cornea about three millimetres from the limbus. This area is painted with 5 per cent. iodine solution. The eye is now fixed by an assistant, and a puncture made through the painted area in a plane parallel to the iris. This puncture is made with a special needle devised by Professor Amsler which is placed on a 1 c.c. (tuberculin) syringe.

- Received for publication, January 29, 1947. 